\title{
Effects of dietary energy allowance and decline in dry matter intake during the dry period on responses to glucose and insulin in transition dairy cows
}

\author{
S. Salin, ${ }^{* 1}$ A. Vanhatalo, ${ }^{*}$ K. Elo, ${ }^{*}$ J. Taponen, $\dagger$ R. C. Boston, $\ddagger$ and T. Kokkonen* \\ *Department of Agricultural Sciences, University of Helsinki, FI-00014 Helsinki, Finland \\ †Department of Production Animal Medicine, University of Helsinki, FI-04920 Saarentaus, Finland \\ ¥New Bolton Center, University of Pennsylvania, Kennett Square 19348
}

\section{ABSTRACT}

We assessed whether high energy intake during the early dry period $[144 \%$ of metabolizable energy (ME) requirements/d] followed by a gradual restriction of energy intake in the close-up dry period (119\% of ME/d; HEI) impaired whole-body insulin sensitivity compared with a controlled energy intake (100\% of ME/d; CEI) throughout the 6 -wk dry period. Multiparous Ayrshire dairy cows $(\mathrm{n}=16)$ were blocked by body weight, body condition score, and expected date of parturition and were used in a randomized complete block design until $10 \mathrm{~d}$ after parturition. Cows were fed either HEI or CEI diets based on grass silage during the first $3 \mathrm{wk}$ of the dry period and grass silage supplemented with a commercial concentrate (30\% of ME intake) during the final 3 wk of gestation. After calving, all cows were fed grass silage ad libitum and an increasing amount of commercial concentrate (maximum $9 \mathrm{~kg}$ at d 10 postpartum). Intravenous glucose tolerance tests (IVGTT) and intravenous insulin challenges were performed -10 $\pm 5 \mathrm{~d}(\mathrm{n}=15)$ and $+10 \pm 1 \mathrm{~d}(\mathrm{n}=14)$ relative to parturition. Following glucose injection, we did not find any treatment effects on glucose and insulin responses. The prepartal nonesterified fatty acid (NEFA) response of the HEI group was blunted, basal NEFA and the decrement of NEFA were smaller, and the area under the response curve (AUC) of NEFA was less negative in HEI cows than in CEI cows. The NEFA response reversed after parturition; the NEFA AUC of the HEI group was more negative than that of the CEI group. We did not find similar responses after insulin injection. Across the treatments, NEFA AUC correlated strongly with the basal NEFA concentration during the IVGTT pre- and postpartum. Calculated and model-based indices characterizing the overall glucose tolerance and $\beta$-cell function and the insulin sensitivity were higher after parturition than during the dry pe-

Received August 15, 2016.

Accepted March 11, 2017.

${ }^{1}$ Corresponding author: siru.salin@helsinki.fi riod. Consistent with the lower basal insulin, the acute insulin release after the glucose infusion was smaller in postpartal IVGTT than in prepartal IVGTT. The results suggest that whole-body insulin sensitivity of the cows increased after parturition. However, the role of peripheral insulin sensitivity in the regulation of glucose partitioning seems to be minor relative to the major change in insulin secretion and clearance during the periparturient period.

Key words: insulin resistance, transition dairy cow, grass silage, feed intake

\section{INTRODUCTION}

The transition from late pregnancy to early lactation is an enormous challenge for the metabolic flexibility of dairy cows. During this period, a moderate insulin resistance (IR) of peripheral tissues is developed (Sano et al., 1993; Bell and Bauman, 1997; Vernon and Pond, 1997). As recently reviewed by Remppis et al. (2011) and Roche et al. (2009, 2013), overconsumption of dietary energy during the dry period and increasing calving BCS compromise the increase in DMI in the early postpartum period compared with controlled dry period energy intake (EI). The increase in DMI is fundamental for the adaptation to the abrupt change in energy requirements to support lactation. An excess allowance of energy in the dry period may result in a pronounced decline in DMI before parturition (Dann et al., 2006; Douglas et al., 2006; Janovick and Drackley, 2010), although the decline in prepartal DMI is not universal (Agenäs et al., 2003; Dewhurst et al., 2009; Roche et al., 2013). However, overconditioning in the dry period has resulted in lower DMI in early lactation (Agenäs et al., 2003; Dann et al., 2006; Janovick and Drackley, 2010). Overfeeding combined with naturally occurring maternal IR may exacerbate mobilization of nonesterified fatty acids (NEFA) from the adipose tissue, resulting in higher plasma NEFA during early lactation. Elevated NEFA interferes with insulin-stimulated glucose and fatty acid metabolism in dairy cows (Pires et al., 2007, 2008; Salin et al., 2012). An aggravated 
lipolysis may result in the accumulation of lipids in the liver and likely contributes to the increased susceptibility of metabolic disorders in periparturient dairy cows (Grummer et al., 2004; Drackley et al., 2005).

Recent research investigating the effects of the transition period, alone or together with different prepartal dietary regimens, on insulin responsiveness and insulin sensitivity has suggested that IR may have tissuespecific features (Schoenberg et al., 2012; Zachut et al., 2013; De Koster et al., 2015). These results demonstrated that IR in adipose tissue occurred only in cows that were losing the most $\mathrm{BW}$ and that overconditioned dairy cows did not develop hepatic IR as a result of overfeeding during the dry period (Zachut et al., 2013). Intravenous glucose tolerance tests (IVGTT) and hyperinsulinemic-euglycemic tests have revealed that dry late pregnant cows have different sensitivities to insulin at the level of carbohydrate and fatty acid metabolism in response to different dry period feeding regimens, inducing differences in BCS (Schoenberg and Overton, 2011; Schoenberg et al., 2012; De Koster et al., 2015). Hyperinsulinemic-euglycemic tests conducted around $20 \mathrm{~d}$ prepartum in overconditioned and normalconditioned dairy cows under similar EI suggested that, analogous to humans, fatty acid metabolism is more sensitive to the actions of insulin than glucose metabolism (Swislocki et al., 1987; De Koster et al., 2015). The effects of lipid accretion on insulin response of the fatty acid metabolism in dairy cows at the end of the dry period were negligible, whereas the insulin response of the glucose metabolism was weakened in overconditioned dry cows (De Koster et al., 2015). However, insulin signaling in adipose tissue was not impaired by prepartal overfeeding (Ji et al., 2012; Selim et al., 2014). Some earlier studies have suggested that insulin-sensitive tissues of ruminants, and especially those of dairy cows, may be more refractory to the actions of insulin during the late prepartal period than they are shortly after calving (Petterson et al., 1993; Kräft, 2004; Smith et al., 2004). Others, however, have reported opposite results (Sano et al., 1993; Holtenius et al., 2003).

The primary objective was to test the hypothesis that overconsumption of grass silage during the far-off dry period (6 to 4 wk prepartum) combined with decreasing feed allowance during the close-up dry period (the final 3 wk of pregnancy) causes the insulin sensitivity of dairy cows to deteriorate before parturition and that this effect carries over into early lactation. The animal model approach applied in this study was chosen to ensure that the anticipated decline in DMI would actually happen in high EI cows during the close-up dry period. Experimental evidence of a dramatic decrease in DMI with grass silage-based diets is scarce, and the few studies conducted with these types of diets (Agenäs et al., 2003; Dewhurst et al., 2009) have not shown declines (up to $30 \%$ during the last 3 wk of pregnancy) as extreme as those reported by Grummer et al. (2004) in mainly maize and alfalfa forage-based diets. Additionally, we assessed time and diet $\times$ time interactions of metabolic responses related to glucose and insulin dynamics in periparturient dairy cows.

\section{MATERIALS AND METHODS}

\section{Animals, Diets, and Experimental Design}

All experimental procedures were conducted under the protocols approved by the National Animal Ethics Committee in Finland in accordance with guidelines established by the European Community Council Directive 86/609/EEC. Sixteen multiparous pregnant dry Finnish Ayrshire dairy cows were used in a randomized complete block design. The cows were paired according to expected calving date, parity (second through fourth), BW (693 $\pm 57 \mathrm{~kg}$; mean $\pm \mathrm{SD})$, and BCS (3.7 \pm 0.3 ; mean $\pm \mathrm{SD}$ ). Within pairs, cows were randomly assigned to 1 of the 2 prepartal dietary treatments 6 wk before the expected parturition ( $44 \pm 5 \mathrm{~d}$ before the actual calving day; mean $\pm \mathrm{SD}$ ).

The dietary treatments were (1) controlled feed allowance (controlled energy intake, CEI) to meet $100 \%$ of the calculated ME requirements of a pregnant cow and (2) high feed allowance (high energy intake, HEI) to meet $150 \%$ of the ME requirements of a pregnant cow (Natural Resources Institute Finland, 2015) during the far-off dry period (6 to 4 wk prepartum). In the HEI group, feed allowance was decreased during the last 3 wk $(24 \pm 5 \mathrm{~d})$ of pregnancy by gradually restricting DMI ( $5 \%$ decrement every 2 d) to meet the energy requirements by the day of the expected calving. This design was applied to study the combined effect of a high EI during the far-off dry period and the subsequent decline in DMI with approaching calving observed previously in abundantly fed overconditioned cows (Grummer et al., 2004; Dann et al., 2006; Douglas et al., 2006). Both groups were fed wilted grass silage during the first 3 wk of the dry period and wilted grass silage supplemented with a commercial concentrate (30\% of calculated ME intake/d) during the final $3 \mathrm{wk}$ of pregnancy. In the case of postdate pregnancies, the same amount of feed was offered until the due date. The chemical composition and calculated energy content of the forages and the concentrates are given in Table 1. From dry-off to parturition, $0.2 \mathrm{~kg}$ of a proprietary dry-cow mineral supplement (Tunnu-Melli, Raisio Feed Ltd., Raisio, Finland) was top dressed once daily on forage (Supplemental Table S1; https://doi.org/10.3168/ jds.2016-11871). After calving, cows were given wilted 
SALIN ET AL.

Table 1. Chemical composition and energy content of forages and concentrates

\begin{tabular}{lcccc}
\hline & Grass & Grass & & \\
Item & silage $1^{1}$ & silage $2^{2}$ & Concentrate $1^{3}$ & Concentrate $2^{4}$ \\
\hline DM $(\mathrm{g} / \mathrm{kg})$ & 239 & 236 & 869 & 870 \\
Ash $(\mathrm{g} / \mathrm{kg}$ of $\mathrm{DM})$ & 87 & 71 & 69 & 83 \\
$\mathrm{CP}(\mathrm{g} / \mathrm{kg}$ of $\mathrm{DM})$ & 155 & 146 & 202 & 303 \\
Ether extract $(\mathrm{g} / \mathrm{kg}$ of $\mathrm{DM})$ & 50 & 45 & 62 & 87 \\
$\mathrm{NDF}(\mathrm{g} / \mathrm{kg}$ of DM) & 506 & 532 & 206 & 243 \\
ME $(\mathrm{MJ} / \mathrm{kg}$ of $\mathrm{DM})$ & 10.6 & 11.2 & 12.9 & 12.9 \\
\hline
\end{tabular}

${ }^{1}$ Grass silage fed during the dry period. Mean fermentation characteristics in DM (\%): lactic acid, 3.81; acetic acid, 1.06; butyric acid, 0.12. Percentage of total $\mathrm{N}$ ammonium-N, 9.1; soluble N, 60.1. pH = 4.48.

${ }^{2}$ Grass silage fed during lactation. Mean fermentation characteristics in DM (\%): lactic acid, 3.91; acetic acid, 1.50; butyric acid, 1.81. Percentage of total $\mathrm{N}$ ammonium-N, 5.5; soluble N, 61.5. $\mathrm{pH}=3.96$.

${ }^{3}$ Concentrate fed during the last 3 wk of pregnancy and during lactation. Mean composition in DM (\%): barley, 27.63; rapeseed cake and meal, 20.00; molasses, 12.50; wheat, 12.00; soybean meal, 5.10; barley malt feed, 5.0; hulled oats, 4.0; dried brewers grain, 3.80; wheat feed meal, 3.60; wheat bran, 2.0; vegetable oil mix, 1.7; calcium carbonate, 1.10 ; salt, 0.67 ; magnesium oxide, 0.35 ; premixes, 0.25 ; sodium bicarbonate, 0.20 ; biotin premix, 0.10 .

${ }^{4}$ Protein supplement fed during lactation. Mean composition in DM (\%): rapeseed cake and meal, 50.80; molasses, 21.50; soybean meal, 14.00; wheat feed meal, 5.80; barley malt feed, 2.00; protected fat, 2.00; propylene glycol premix, 1.40; vegetable oil mix, 1.20; salt, 0.65; premixes, 0.45; biotin premix, 0.20 .

grass silage ad libitum and a ration of commercial concentrate: $86 \%$ of the daily amount as cereal-based concentrate (Krono III) and $14 \%$ as a protein supplement (Multi-Krono Top), which were both provided by the same supplier (Suomen Rehu, Hankkija Agriculture Ltd., Hyvinkää, Finland). Additionally, the cows received $0.2 \mathrm{~kg} / \mathrm{d}$ of a proprietary mineral supplement (Pihatto-Melli, Raisio Feed Ltd.; Supplemental Table S1; https://doi.org/10.3168/jds.2016-11871). The daily amount of concentrate was gradually incremented from $5 \mathrm{~kg} / \mathrm{d}$ on the day of calving to a maximum amount of $9 \mathrm{~kg} / \mathrm{d}$ on d 10 after calving.

The cows were housed in tie stalls that had rubber mats covered with sawdust bedding and were equipped with automatic water and feed troughs (Insentec BV, Marknesse, the Netherlands). Approximately 1 wk before the expected calving, the cows were moved to individual calving pens. The cows were returned to the tie stalls 2 to $5 \mathrm{~d}$ after parturition. Cows were fed twice daily at 0700 and $1700 \mathrm{~h}$ during the dry period and 5 times daily postpartum. After parturition, the cows were milked twice daily at 0600 and $1630 \mathrm{~h}$. The individual feed intake of the cows was recorded daily throughout the experiment, including the time cows spent in calving pens. The cows were weighed biweekly on 2 consecutive days during the dry period and were weighed $5 \mathrm{~d}$ prepartum and $1,3,5,7$, and $14 \mathrm{~d}$ postpartum on 2 consecutive days. Throughout the experiment, BCS was recorded using a 5-point scaling system by 1 person at the same time points when the cows were weighed (Edmonson et al., 1989). In the case of postdate pregnancies, additional weighing was done on alternate days until the due date.
Data reported here were collected from cows subjected to a longer experimental period; feed and EI, weekly measured plasma hormones and metabolites, and production data for this period are reported in a companion paper [T. Kokkonen, S. Salin, S. Jaakkola (University of Helsinki), J. Taponen, K. Elo, and A. Vanhatalo, unpublished data]. The results of the gene expression patterns in the subcutaneous adipose tissue and liver as well as the hepatic lipid content of the cows are reported elsewhere (Selim et al., 2014). The duration of the experimental period covered in this article was -6 wk to +10 d relative to parturition.

\section{Sampling and Analysis of the Feeds}

Representative samples of silage and concentrates were collected on a weekly basis, composited, and stored at $-20^{\circ} \mathrm{C}$. Standard procedures were used for the feed analysis as described elsewhere [Salin et al., 2012; Selim et al., 2014; T. Kokkonen, S. Salin, S. Jaakkola (University of Helsinki), J. Taponen, K. Elo, and A. Vanhatalo, unpublished data].

\section{IVGTT and IC}

Intravenous glucose tolerance tests were performed $10 \pm 5 \mathrm{~d}$ (mean $\pm \mathrm{SD} ; \mathrm{n}=15)$ before the actual day of parturition and $10 \pm 1 \mathrm{~d}$ postpartum $(\mathrm{n}=14)$ at $0830 \mathrm{~h}$. Feed but not water was withheld $1 \mathrm{~h}$ before and during the IVGTT and the insulin challenge (IC). On the previous day at $1500 \mathrm{~h}$, sterile indwelling catheters [left: Intraflon 14 G (Vygon, Ecouen, France); right: homemade catheter made of silicone tubing] 
were inserted into jugular veins and sutured to the skin (Vetafil Bengen, Hannover, Germany). A 25-cm polyvinyl chloride elongation tube (Connecta, BD Medical, Franklin Lakes, NJ) was connected to the catheters. To prevent the cow from manipulating and dislodging the catheters, the entire neck was wrapped with elastic bandages (Optiplaste-C $10 \mathrm{~cm}$, BSN Medical AB, Stockholm, Sweden). The left catheter was used for the infusion of glucose and insulin, and the right catheter was used for the collection of blood samples.

Before initiating the metabolic challenges, the catheters were checked for patency, primed by discarding a blood volume of $10 \mathrm{~mL}$, flushed with a sterile saline solution $(0.9 \% / \mathrm{vol} \mathrm{NaCl})$, and left filled with sterile heparinized saline $[1 \mathrm{~mL}$ of heparin (heparin sodium, $5,000 \mathrm{IU} / \mathrm{mL}) / 100 \mathrm{~mL}$ of $0.9 \% / \mathrm{vol} \mathrm{NaCl}$. After the administration of glucose or insulin, the catheters were flushed with $20 \mathrm{~mL}$ of saline solution and left filled with heparinized saline when not in use. Before the collection of each sample, the catheters were primed by discarding a minimum of $5 \mathrm{~mL}$ of blood. After each sampling, the catheters were filled with $5 \mathrm{~mL}$ of heparinized saline. The blood samples were collected via the catheters at $-15,-5,5,10,15,20,30,40,50,60,90$, 120,150 , and $180 \mathrm{~min}$ relative to the infusion of $0.25 \mathrm{~g}$ of glucose $/ \mathrm{kg}$ of BW (Glucos. $300 \mathrm{mg} / \mathrm{mL}$, B. Braun, Melsungen, Germany) over $6.5 \pm 3.5$ min (mean $\pm \mathrm{SD}$ ) and $4.2 \pm 1.7 \mathrm{~min}$ pre- and postpartum, respectively. The blood samples were handled as described earlier (Salin et al., 2012).

To further assess maximal tissue responses to insulin during a period of time when the cows are most likely to be insulin resistant because of late pregnancy and early lactation (Bauman and Currie, 1980), an IC was performed at $1900 \mathrm{~h}$ on the day of the IVGTT (n $=15$ prepartum; $\mathrm{n}=13$ postpartum). This approach was chosen to avoid putting any extra stress on the cows because they were already acclimatized to the handling procedures used during the IVGTT. The IC was conducted by intravenous administration of $0.1 \mathrm{IU}$ of short-acting insulin/kg of BW (100 IU/mL; Humulin Regular human insulin rDNA origin; Lilly Pharma Fertigung and Distribution GmbH and Co., Giessen, Germany). Priming and flushing of the catheters were performed according to the IVGTT procedures, and blood samples were collected at $-15,-5,5,10,15,20$, $30,40,50,60,90$, and 120 min relative to the administration of the insulin bolus.

The data set of 1 animal in the CEI group is missing from the statistical analysis of the prepartal IVGTT and IC because of premature parturition. Further, the data sets of 2 cows, 1 from each treatment group, were excluded from the postpartal statistical analysis because of health problems. One cow suffered from sciatic nerve paralysis, and the other was excluded from the trial as a result of prolonged periods of inappetence. Additionally, 1 cow in the HEI group suffered from hypoglycemic shock 30 min after the postpartal insulin injection (blood glucose $<2.0 \mathrm{mmol} / \mathrm{L}$ ). For this cow, basal and nadir values as well as the area under the response curve (AUC) and clearance rate (CR) during the first $30 \mathrm{~min}$ of the challenge were included in the statistical model. During IC, technical problems occurred with several animals due to clotting of the right catheter, so the blood samples were collected from the left catheter, through which the insulin infusion had been administered. For unknown reasons and despite the flushing procedure between each sampling, the plasma samples of these animals were beyond the detection range of the insulin assay. Because much of the insulin data during IC were missing, the insulin results were not subjected to statistical analysis and are not shown in the results section. The results of calculated parameters of glucose and NEFA dynamics during the IC are shown for 15 and 13 cows in prepartal and postpartal IC, respectively.

Blood samples were analyzed for plasma glucose and NEFA as described earlier (Salin et al., 2012) with intra- and interassay coefficients of variation (CV) of 2.9 and $2.0 \%$ for glucose and 2.9 and $1.2 \%$ for NEFA, respectively. Plasma insulin was analyzed by a solid-phase, 2-site, bovine-specific enzyme immunoassay method (Bovine Insulin ELISA, Mercodia AB, Uppsala, Sweden) with an intraassay CV of $8.2 \%$ and interassay CV of 9.5 and $7.7 \%$ for low $(0.53 \mu \mathrm{g} / \mathrm{L}$; range $=0.43-0.64 \mu \mathrm{g} / \mathrm{L})$ and medium $(1.44 \mu \mathrm{g} / \mathrm{L}$; range $=$ $1.24-1.64 \mu \mathrm{g} / \mathrm{L})$ concentrations, respectively.

\section{Calculation and Statistical Analysis}

Plasma glucose, insulin, and NEFA responses to the metabolic challenges were calculated as a net incremental AUC $(\mathrm{mmol} / \mathrm{L} \times$ min for glucose and NEFA; $\mu \mathrm{IU} /$ $\mathrm{mL} \times \min$ for insulin) during the first 60 and $180 \mathrm{~min}$ of the IVGTT and 30 and 120 min of the IC using the actual concentration values. The net incremental AUC was calculated by SAS (version 9.3; SAS Institute Inc., Cary, NC) using the trapezoidal rule (Shiang, 2004) in which basal concentrations were calculated as mean concentrations of the blood samples taken 15 and 5 min before the IVGTT and IC. The NEFA decrement was calculated by subtracting the nadir concentrations from the basal concentrations. Clearance rates of metabolites and hormones during the challenges were calculated as described previously (Pires et al., 2007; Salin et al., 2012).

Estimates of glucose use were calculated assuming that the net incremental AUC of glucose during 180 
min of IVGTT represents (1) total glucose exposure and (2) complete disposal of infused glucose (i.e., the state when glucose concentration has returned to basal level). Accordingly, $\mathrm{AUC}_{180}$ represents a state when all exogenous glucose is used, and AUC at time $t$ represents a state of partial glucose exposure when $\mathrm{AUC}_{t} /$ $\mathrm{AUC}_{180} \times 100 \%$ of exogenous glucose is used. The glucose requirement of the gravid uterus was assumed to be $0.10 \mathrm{~mol} / \mathrm{kg}$ of fetus per day, and the glucose requirement of the mammary gland during lactation was $0.4 \mathrm{~mol} / \mathrm{kg}$ of milk (as summarized by De Koster and Opsomer, 2013). These estimates were used to calculate the glucose requirement (per hour) of the gravid uterus and milk synthesis during IVGTT. Glucose use for milk synthesis was assumed to be constant during IVGTT because no change in the rate of lactose synthesis of isolated bovine mammary cells over the range of 3 to 20 $\mathrm{mmol} / \mathrm{L}$ of glucose has been reported (Rao et al., 1975). The excretion of glucose in the urine was assumed to be $5 \%$ of the infused amount based on observations by Grünberg et al. (2011) showing that 4 to $7 \%$ of dextrose was excreted in the urine during the IVGTT using an infusion dose of 0.3 to $0.4 \mathrm{~g} / \mathrm{kg}$ of BW.

For each IVGTT, the minimal model (MM; Bergman, 1989) was applied to glucose and insulin data using commercial software (MinMod Millenium, Minmod Inc., Pasadena, CA) with methods that were described previously (Boston et al., 2003; Salin et al., 2012). Briefly, the model provides values for insulin sensitivity index (SI; $\left.10^{-4} \mathrm{~min}^{-1} \mu \mathrm{IU}^{-1} \mathrm{~mL}\right)$, defined as the fractional rate of glucose uptake per unit of plasma insulin; glucose effectiveness $\left(\mathrm{min}^{-1}\right)$, which characterizes non-insulin-mediated glucose disposal; acute insulin response to glucose (AIRg; $\mu \mathrm{IU} / \mathrm{mL}$ per minute), which represents the endogenous insulin response to a glucose bolus; and disposition index (DI), a measure of overall glucose tolerance that is calculated as the product of SI and AIRg.

For the further evaluation of the NEFA dynamics during the IVGTT, a NEFA model was used (Boston and Moate, 2008). The model generates the following parameters: FFA0 $(\mu \mathrm{mol} / \mathrm{L})$, the initial plasma NEFA concentration at time zero relative to glucose infusion; $\mathbf{S}_{\text {FFA }}(\mu \mathrm{mol} / \mathrm{L}$ per minute), which describes the maximal rate of net provision of NEFA to the plasma pool; and $\mathbf{K}_{\mathrm{FFA}}\left(\mathrm{min}^{-1}\right)$, a rate constant of NEFA disappearance from the plasma pool.

Data from IVGTT $(-10 \mathrm{~d}$ and $+10 \mathrm{~d}$ relative to calving) were combined and analyzed by ANOVA using the MIXED procedure of SAS (version 9.3; SAS Institute Inc., Cary, NC) with a repeated measures model that included fixed effects of treatment and day, an interaction of day and treatment, and random effects of block and cow within block. Prior to statistical analysis, re- siduals of all data were checked for normality using the MIXED and UNIVARIATE procedures of SAS. The data of BW, BSC, feed intake, animal performance, and weekly plasma hormone and metabolite concentrations were analyzed as described in Selim et al. (2014).

The relationships between plasma concentrations, parameters describing insulin sensitivity, and the interval between the sampling day and the actual day of parturition were investigated by Spearman's correlation analysis using the CORR procedure of SAS. All values in the tables are reported as least squares means and standard error of the mean, whereas in the figures arithmetic means with error bars represent \pm 1 standard error of the mean calculated from the data. Logarithmic transformation was used to correct for deviations from normality and homoscedasticity of residuals when needed. In those cases, the untransformed values with $P$-values from the statistical analysis of the natural logarithmic transformed values are presented. The treatment and treatment by day effects were considered statistically significant at $P<0.05$, and trends for the effects are discussed at $0.05 \leq P<0.10$.

\section{RESULTS}

\section{Animal Performance}

The average difference between the treatments in $\mathrm{ME}$ intake during the first $3 \mathrm{wk}$ of the dry period was $42 \%$ (141 and $99 \mathrm{MJ} / \mathrm{d}$ for HEI and CEI cows, respectively; $\mathrm{SEM}=3.3 ; 144 \%$ vs. $100 \%$ of $\mathrm{ME}$ requirements). The average DMI of silage was 12.6 and $8.9 \mathrm{~kg} / \mathrm{d}$ (SEM $=0.26 ; P<0.01)$ in HEI and CEI cows, respectively. During the final $3 \mathrm{wk}$ of pregnancy, the differences in ME intake (128 vs. $109 \mathrm{MJ} / \mathrm{d}$; SEM $=1.8 ; 119 \%$ vs. $100 \%$ of ME requirements) and DMI (11.5 vs. $9.5 \mathrm{~kg} / \mathrm{d}$; $\mathrm{SEM}=0.15)$ diminished between HEI and CEI cows after a decreasing energy allowance was imposed on HEI cows. The average daily DMI during the last $2 \mathrm{wk}$ of the dry period in HEI and CEI cows was 11.0 and $9.9 \mathrm{~kg} / \mathrm{d}$, respectively $(\mathrm{SEM}=0.27 ; P=0.01)$, and the corresponding average values during the first $14 \mathrm{~d}$ of lactation were 17.7 and $16.7 \mathrm{~kg} / \mathrm{d}$, respectively $(\mathrm{SEM}=$ $0.71 ; P=0.01)$. The ECM during the first $14 \mathrm{~d}$ of lactation was 33.4 and $33.9 \mathrm{~kg} / \mathrm{d}(\mathrm{SEM}=1.35 ; P=0.74)$ in HEI and CEI cows, respectively. Plasma metabolites and hormone concentrations (glucose, insulin, NEFA, $\mathrm{BHB}$, and glucagon) at $\mathrm{d}-10,+1$, and +7 relative to parturition were not different in HEI and CEI cows (Selim et al., 2014). However, mean insulin concentration tended to be higher in HEI cows than in CEI cows during the dry period (24.2 vs. $15.9 \mu \mathrm{IU} / \mathrm{mL}$; SEM $=4.79 ; P=0.09)$. No treatment effects were found in either BW or BW change during the dry period or 
during early lactation $(P>0.10)$. The average BW, BCS, and energy balance values of the cows in the HEI group versus cows in the CEI group at 2 wk preceding calving were 729 versus $722 \pm 18.7 \mathrm{~kg}, 3.7$ versus 3.8 \pm 0.11 , and 24.9 versus $4.1 \pm 4.99 \mathrm{MJ}$ of $\mathrm{ME} / \mathrm{d}$. The average $\mathrm{BW}, \mathrm{BCS}$, and energy balance values at $+2 \mathrm{wk}$ of lactation were 657 versus $639 \pm 18.7 \mathrm{~kg}, 3.3$ versus $3.2 \pm 0.11$, and -71.5 versus $-65.4 \pm 4.99 \mathrm{MJ}$ of $\mathrm{ME} / \mathrm{d}$ $(P>0.10$; Selim et al., 2014).

\section{Glucose Dynamics During the IVGTT}

The overall change in plasma glucose is illustrated in Figures $1 \mathrm{~A}$ and $2 \mathrm{~A}$ and in Table 2. All cows adapted to the variations of the glucose dynamics in a similar manner prepartum regardless of how close to the actual day of calving they were during the prepartal IVGTT $(P>$ $0.10)$. As anticipated, plasma glucose decreased after parturition (4.4 vs. $3.1 \mathrm{mmol} / \mathrm{L} ; P<0.001$ ). Similarly, peak value of glucose (17.0 vs. $15.5 \mathrm{mmol} / \mathrm{L} ; P=0.01)$ and AUC during the IVGTT (441 vs. $308 \mathrm{mmol} / \mathrm{L} \times$ $180 \mathrm{~min} ; P<0.001)$ were lower after parturition across treatments. The CR at $60 \mathrm{~min}$ of glucose was increased after calving ( 1.7 vs. $2.7 \% / \mathrm{min} ; P<0.001)$.

\section{Insulin Response to Glucose Infusion During the IVGTT}

Prepartal dietary treatment did not affect the endogenous insulin response to glucose infusion $(P>$ $0.10)$. The interindividual variation in insulin response was high, especially during the prepartal IVGTT, as illustrated in Figures 1B and 2B. Basal insulin concentration before the IVGTT was unexpectedly high in both treatments prepartum (Table 2) and decreased considerably after calving ( 42.6 vs. $8.0 \mu \mathrm{IU} / \mathrm{mL} ; P<$ 0.001). No significant effects of the interval between the IVGTT and the day of calving were observed in insulin dynamics prepartum. The overall insulin response to glucose altered after parturition $(P<0.01)$. In addition to the decline in basal insulin, peak insulin (357 vs. 129 $\mu \mathrm{IU} / \mathrm{mL}$ ) and the $\mathrm{AUC}_{180}$ of insulin (13,510 vs. 3,673 $\mu \mathrm{IU} / \mathrm{mL} \times 180 \mathrm{~min})$ decreased after calving, whereas the $\mathrm{CR}$ at $60 \mathrm{~min}$ of insulin increased (0.73 vs. $2.4 \%$ / min; $P<0.001)$.

\section{Glucose Use During the IVGTT}

Average amounts of glucose infused for CEI and HEI were 178.5 and $181.5 \mathrm{~g}$, respectively, in the prepartal IVGTT and 162.8 and $169 \mathrm{~g}$, respectively, in the postpartal IVGTT. Based on the ratio of glucose AUC $\left(\mathrm{AUC}_{30} / \mathrm{AUC}_{180}\right), 54$ and $68 \%$ of the infused glucose was disposed during the first $30 \mathrm{~min}$ of the pre- and
A

$10 \mathrm{~d}$ prepartum
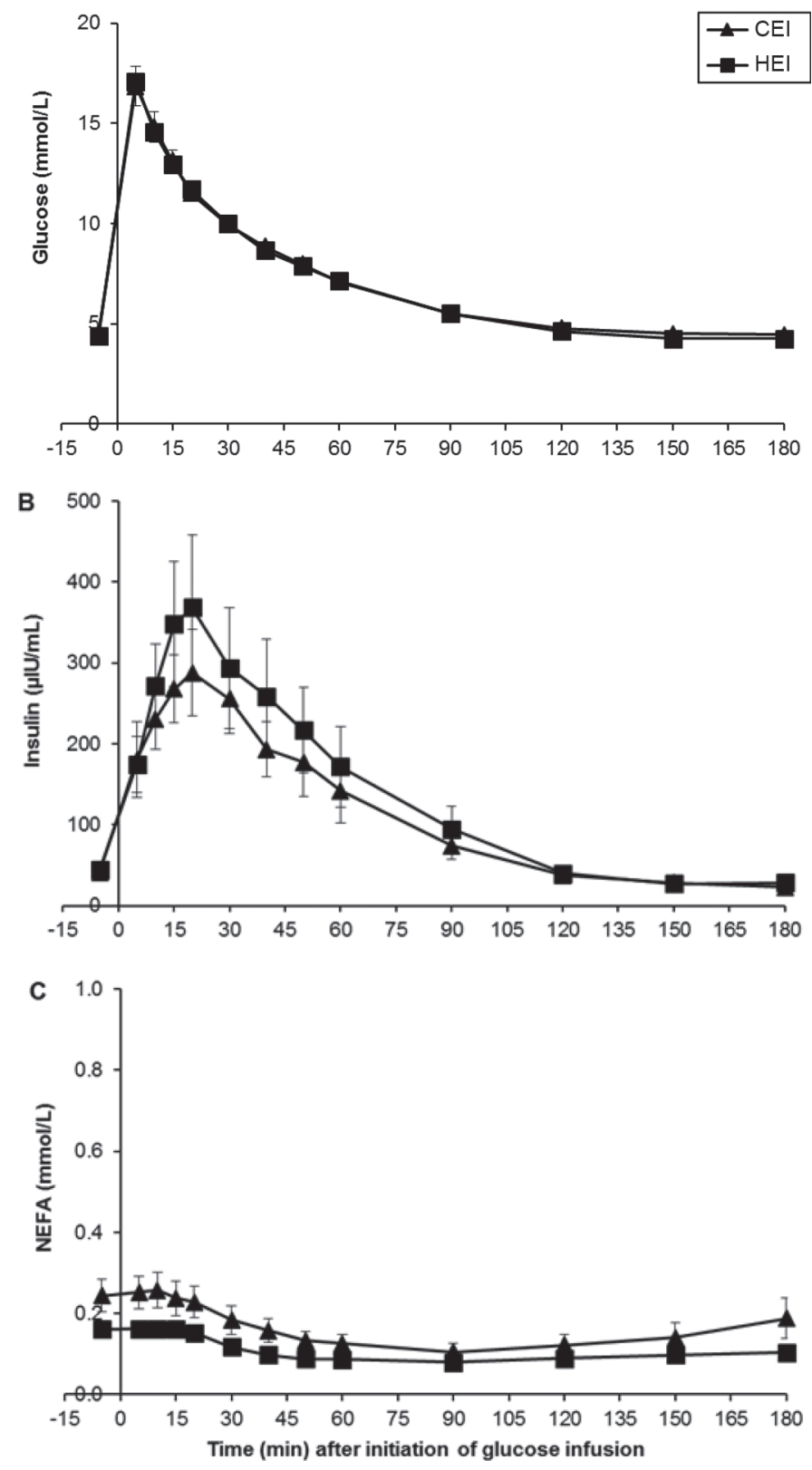

Figure 1. Treatment effects on plasma (A) glucose, (B) insulin, and $(\mathrm{C})$ nonesterified fatty acid (NEFA) concentration during intravenous glucose tolerance tests $(0.25 \mathrm{~g}$ of glucose i.v. $/ \mathrm{kg}$ of $\mathrm{BW})$ performed $10 \mathrm{~d}$ before parturition in dairy cows fed $100 \%$ of ME requirements throughout the 6-wk dry period (CEI) and cows fed $144 \%$ of $\mathrm{ME}$ requirements during the early dry period followed by a gradual restriction of energy intake ( $119 \%$ of ME requirements) during the last $3 \mathrm{wk}$ of gestation (HEI). Error bars represent the standard error of the mean calculated from the data. Least squares means of the area under the curve for glucose, NEFA, and insulin were $441 \pm 15.4 \mathrm{mmol} / \mathrm{L} \times$ $180 \mathrm{~min},-13.3 \pm 4.4 \mathrm{mmol} / \mathrm{L} \times 180 \mathrm{~min}$, and $13,510 \pm 2,352 \mu \mathrm{IU} /$ $\mathrm{mL} \times 180 \mathrm{~min}(\mathrm{n}=15)$, respectively. The concentration at time point -5 min represents the average concentration at 15 and 5 min before intravenous glucose tolerance tests. 

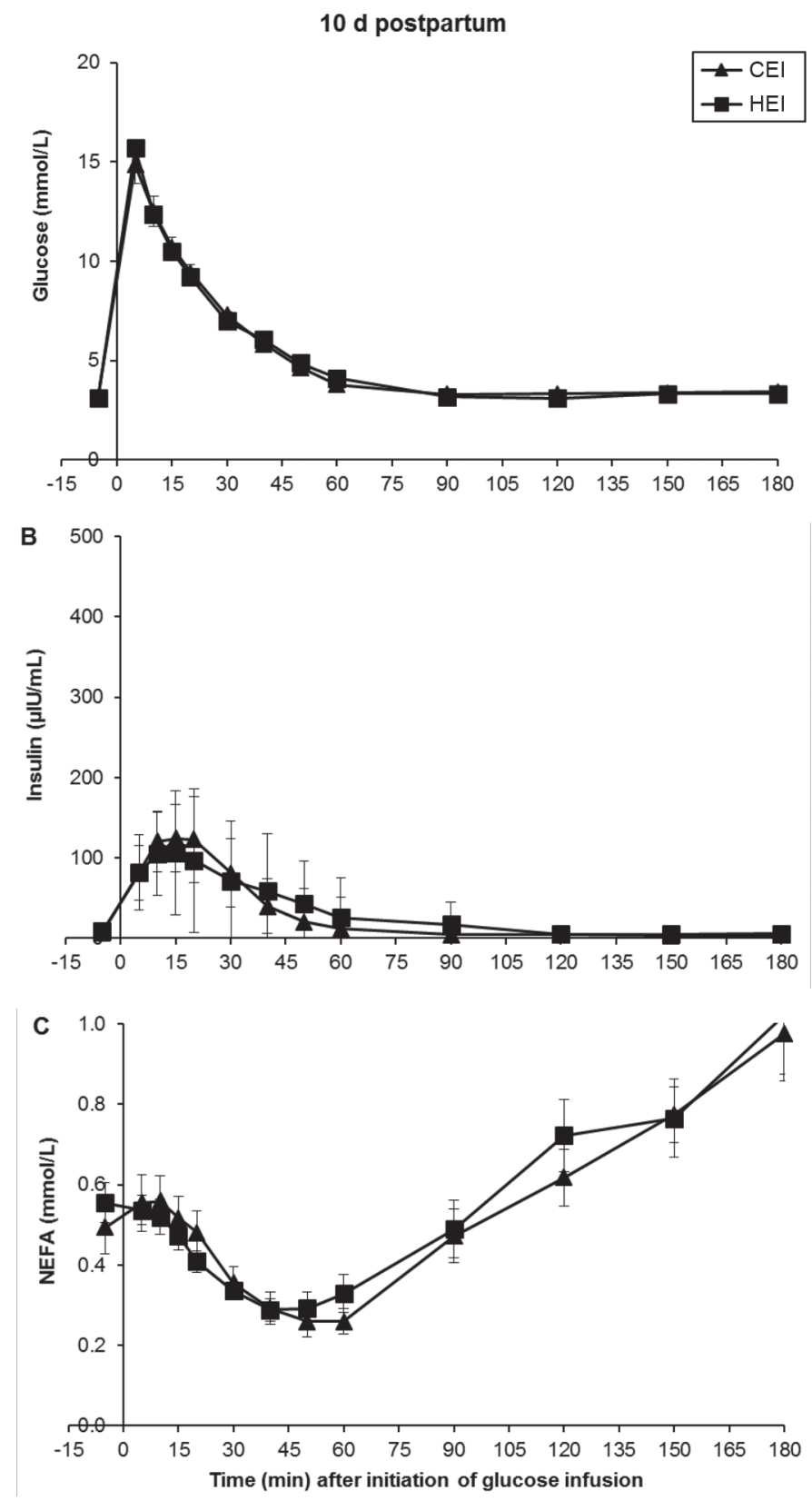

Figure 2. Treatment effects on plasma (A) glucose, (B) insulin, and $(\mathrm{C})$ nonesterified fatty acid (NEFA) concentration during intravenous glucose tolerance tests $(0.25 \mathrm{~g}$ of glucose i.v. $/ \mathrm{kg}$ of $\mathrm{BW})$ performed $10 \mathrm{~d}$ after parturition in dairy cows fed $100 \%$ of ME requirements throughout the 6 -wk dry period (CEI) and cows fed $144 \%$ of $\mathrm{ME}$ requirements during the early dry period followed by a gradual restriction of energy intake (119\% of ME requirements) during the last 3 wk of gestation (HEI). Error bars represent the standard error of the mean calculated from the data. Least squares means of the area under the curve for glucose, NEFA, and insulin were $308 \pm 15.9 \mathrm{mmol} / \mathrm{L} \times$ $180 \mathrm{~min}, 5.4 \pm 4.4 \mathrm{mmol} / \mathrm{L} \times 180 \mathrm{~min}$, and $3,673 \pm 2,416 \mu \mathrm{IU} / \mathrm{mL} \times$ $180 \min (\mathrm{n}=14)$, respectively. Concentration at time point $-5 \mathrm{~min}$ represents the average concentration at 15 and 5 min before intravenous glucose tolerance tests. postpartal IVGTT, respectively. During the first 30 min of prepartal IVGTT, glucose use for the gravid uterus was estimated to be $16 \mathrm{~g}$, urinary excretion was estimated to be $9 \mathrm{~g}$, and the use of other tissues was estimated to be $73 \mathrm{~g}$. In the postpartal IVGTT, the corresponding values were $54 \mathrm{~g}$ for the mammary gland, $8 \mathrm{~g}$ for urinary excretion, and $51 \mathrm{~g}$ for the use of other tissues. The proportion of other tissues was $74 \%$ in the prepartal IVGTT and $45 \%$ in the postpartal IVGTT. During the first $60 \mathrm{~min}$ of IVGTT, 82 and $91 \%$ of the infused glucose was disposed pre- and postpartum, respectively. In the prepartal IVGTT, the estimated glucose use for the gravid uterus was $33 \mathrm{~g}$ and the use of other tissues was $106 \mathrm{~g}$. In the postpartal IVGTT, the estimated glucose use for the mammary gland was $108 \mathrm{~g}$ and the use of other tissues was $34 \mathrm{~g}$.

\section{Analysis}

Prepartal dietary treatment had no effect on MM estimates except for a tendency $(P<0.10)$ toward higher DI in CEI cows than in HEI cows (Table 2). All cows had lower SI $(P<0.01)$ and DI $(P<0.01)$ and higher AIRg $(P<0.05)$ in the prepartal IVGTT than in the postpartal IVGTT $(P<0.05)$. When data from all cows and both time points were plotted, the relationship between AIRg and SI was hyperbolic (Figure 3). The relationship between basal insulin and SI was also an approximate hyperbola (Figure 4).

\section{Suppression of NEFA During the IVGTT and the NEFA Model Results}

The NEFA response to the glucose load of HEI cows was blunted before calving, but this effect disappeared after parturition (Table 2; Figures $1 \mathrm{C}$ and 2C). The prepartal basal NEFA in HEI cows was around $65 \%$ of the value of CEI cows $(0.16$ and $0.24 \mathrm{mmol} / \mathrm{L}$ in HEI and CEI cows, respectively; $\mathrm{SEM}=0.037$; diet $\times$ time, $P=0.09)$. The NEFA decrement was reduced in HEI cows versus CEI cows $(0.09$ vs. $0.15 \mathrm{mmol} / \mathrm{L}$; SEM $=$ 0.02 ) before but not after calving (diet $\times$ time, $P=$ 0.06). Similarly, the $\mathrm{AUC}_{60}$ of plasma NEFA was less negative in HEI cows versus CEI cows ( -3.0 vs. -2.3 ; $\mathrm{SEM}=1.2)$ before calving, but the reverse ( -6.2 vs. -10.5 ; SEM $=1.25$ ) was observed postpartum (diet $\times$ time, $P=0.03$ ). The basal NEFA was negatively correlated with NEFA AUC $_{60}$ in both prepartal IVGTT $(\mathrm{r}=-0.80 ; P<0.001)$ and postpartal IVGTT $(\mathrm{r}=$ $-0.75 ; P<0.01)$. The CR of NEFA was equal in both treatments $(P>0.10)$ and was similar in all cows during the prepartal and postpartal IVGTT $(P>0.10)$. In contrast to differences in calculated parameters of NEFA disposition, the NEFA model parameters $\mathrm{K}_{\mathrm{FFA}}$ 
and $\mathrm{S}_{\mathrm{FFA}}(P>0.10)$ were not affected by the prepartal dietary treatments (Table 2). In all cows, the parameters $\mathrm{S}_{\mathrm{FFA}}$ and FFA0 were higher $(P<0.001)$ and $\mathrm{K}_{\mathrm{FFA}}$ tended to be higher $(P=0.06)$ postpartum than before parturition. The basal NEFA concentration correlated positively with the glucose $\mathrm{AUC}_{180}$ in the postpartal IVGTT $(\mathrm{r}=0.61 ; P=0.02)$.

\section{Glucose and NEFA Responses to IC}

The plasma glucose and NEFA responses to exogenous insulin during the IC are depicted in Table 3. Mean basal and peak insulin concentrations in IC among the treatments in cows with successful assays were 24.6 and $2,508 \mu \mathrm{IU} / \mathrm{mL}$ and 12.0 and $1,295 \mu \mathrm{IU} /$ $\mathrm{mL}$ for prepartum $(\mathrm{n}=10)$ and postpartum $(\mathrm{n}=11)$ IC, respectively. Following the IC, the glucose response was similar among the treatments $(P>0.10)$; however, the glucose response to exogenous insulin was altered after parturition. After parturition, the basal (4.6 vs. $3.3 \mathrm{mmol} / \mathrm{L}$ ) and nadir (2.6 vs. $1.5 \mathrm{mmol} / \mathrm{L})$ glucose concentrations $(P<0.001)$ as well as the absolute value of glucose $\mathrm{AUC}_{120}(-171$ vs. $-122 \mathrm{mmol} / \mathrm{L} \times 120 \mathrm{~min}$; $P=0.002)$ were smaller, whereas $\mathrm{CR}_{30}$ was greater (1.6 vs. $2.6 \% / \mathrm{min} ; P<0.001)$.

Despite similar patterns of change between treatments in the basal plasma NEFA levels in IC and IVGTT, statistically significant diet $\times$ time interactions were not observed during the IC $(P>0.10)$. The HEI cows tended to have higher $\mathrm{CR}_{30}$ than the CEI cows $(2.7$ vs. $2.0 \% / \mathrm{min} ; P=0.07)$. A greater interval to the actual calving day on the day of the prepartal IC tended to be positively associated with NEFA $\mathrm{CR}_{30}(\mathrm{r}$ $=0.50 ; P=0.06)$ and negatively associated with NEFA

Table 2. Effects of dietary energy and decline in DMI during the dry period on plasma glucose, insulin, and nonesterified fatty acids (NEFA) responses to an intravenous glucose tolerance test (IVGTT; $0.25 \mathrm{~g}$ of glucose/kg of BW) performed $10 \pm 5 \mathrm{~d}(\mathrm{mean} \pm \mathrm{SD}) \mathrm{before}$ and $10 \pm 1 \mathrm{~d}$ after parturition in cows with a controlled energy intake (CEI) and those with a high energy intake (HEI)

\begin{tabular}{|c|c|c|c|c|c|c|c|c|}
\hline \multirow[b]{2}{*}{ Item $^{1}$} & \multicolumn{2}{|c|}{$-10 \mathrm{~d}$} & \multicolumn{2}{|c|}{$+10 \mathrm{~d}$} & \multirow[b]{2}{*}{ SEM } & \multicolumn{3}{|c|}{$P$-value } \\
\hline & CEI & HEI & CEI & HEI & & Treatment & Day $^{2}$ & Treatment $\times$ day $^{2}$ \\
\hline Observations (no.) & 7 & 8 & 7 & 7 & & & & \\
\hline \multicolumn{9}{|l|}{ Glucose } \\
\hline Basal (mmol/L) & 4.4 & 4.4 & 3.2 & 3.1 & 0.15 & 0.76 & $<0.01$ & 0.93 \\
\hline Peak (mmol/L) & 17.0 & 17.1 & 15.1 & 15.9 & 0.60 & 0.44 & 0.01 & 0.52 \\
\hline $\mathrm{CR}_{60}(\% / \mathrm{min})$ & 1.7 & 1.7 & 2.6 & 2.7 & 0.11 & 0.72 & $<0.01$ & 0.91 \\
\hline $\mathrm{AUC}_{180}$ & 441 & 440 & 305 & 310 & 16.11 & 0.94 & $<0.01$ & 0.89 \\
\hline \multicolumn{9}{|l|}{ Insulin } \\
\hline Basal $(\mu \mathrm{IU} / \mathrm{mL})$ & 41.0 & 44.2 & 7.0 & 9.1 & 3.65 & 0.61 & $<0.01$ & 0.91 \\
\hline Peak $(\mu \mathrm{IU} / \mathrm{mL})$ & 331 & 384 & 123 & 135 & 50.5 & $0.83^{*}$ & $<0.01^{*}$ & $0.69^{*}$ \\
\hline $\mathrm{CR}_{60}(\% / \mathrm{min})$ & 0.8 & 0.6 & 2.6 & 2.3 & 0.21 & 0.36 & $<0.01$ & 0.85 \\
\hline $\mathrm{AUC}_{30}$ & 5,540 & 6,990 & 2,555 & 2,647 & 935.1 & 0.45 & $<0.01$ & 0.51 \\
\hline $\mathrm{AUC}_{60}$ & 9,922 & 12,743 & 3,285 & 4,071 & 1,813 & 0.40 & $<0.01$ & 0.63 \\
\hline $\mathrm{AUC}_{180}$ & 11,741 & 15,279 & 3,062 & 4,284 & 2,435 & $0.99^{*}$ & $<0.01^{*}$ & $0.57^{*}$ \\
\hline \multicolumn{9}{|l|}{ NEFA } \\
\hline Basal (mmol/L) & 0.24 & 0.16 & 0.49 & 0.56 & 0.04 & 0.89 & $<0.01$ & 0.09 \\
\hline Decrement (mmol/L) & 0.14 & 0.09 & 0.25 & 0.30 & 0.02 & 0.95 & $<0.01$ & 0.06 \\
\hline $\mathrm{CR}_{60}(\% / \mathrm{min})$ & 1.5 & 1.4 & 1.8 & 1.3 & 0.11 & 0.16 & 0.44 & 0.26 \\
\hline $\mathrm{AUC}_{60}$ & -3.0 & -2.3 & -6.2 & -10.5 & 0.97 & 0.11 & $<0.01$ & 0.03 \\
\hline $\mathrm{AUC}_{180}$ & -15.7 & -10.9 & 8.9 & 1.8 & 4.45 & 0.83 & $<0.01$ & 0.24 \\
\hline \multicolumn{9}{|l|}{ Minimal model } \\
\hline $\mathrm{SI}\left(\times 10^{-4} \min ^{-1} \mu \mathrm{IU}^{-1} \mathrm{~mL}\right)$ & 0.69 & 0.61 & 3.4 & 4.2 & 0.42 & $0.98^{*}$ & $<0.01^{*}$ & $0.82^{*}$ \\
\hline $\mathrm{Sg}\left(\min ^{-1}\right)$ & 0.01 & 0.02 & 0.01 & 0.01 & 0.002 & 0.27 & 0.72 & 0.76 \\
\hline $\operatorname{AIRg}(\mu \mathrm{IU} / \mathrm{mL}$ per minute $)$ & 1,099 & 1,217 & 640 & 605 & 124 & $0.93^{*}$ & $0.01^{*}$ & $0.62^{*}$ \\
\hline DI & 728 & 500 & 2,060 & 1,652 & 132 & $<0.10$ & $<0.01$ & 0.63 \\
\hline \multicolumn{9}{|l|}{ NEFA model } \\
\hline FFA0 $(\mu \mathrm{mol} / \mathrm{L})$ & 243 & 161 & 495 & 563 & 37.3 & $0.45^{*}$ & $<0.01^{*}$ & $0.04^{*}$ \\
\hline $\mathrm{S}_{\mathrm{FFA}}(\mu \mathrm{mol} / \mathrm{L}$ per minute $)$ & 16.4 & 12.7 & 56.8 & 57.7 & 5.04 & $0.42^{*}$ & $<0.01^{*}$ & $0.34^{*}$ \\
\hline $\mathrm{K}_{\mathrm{FFA}}\left(\min ^{-1}\right)$ & 0.03 & 0.05 & 0.05 & 0.05 & 0.005 & 0.21 & 0.058 & 0.23 \\
\hline
\end{tabular}

${ }^{1}$ Basal $=$ average concentration at 15 and 5 min before IVGTT; $\mathrm{CR}_{60}=$ clearance rate during the first 60 min of IVGTT; $\mathrm{AUC}_{180}=$ area under

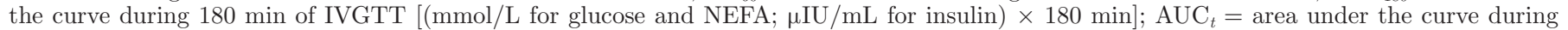

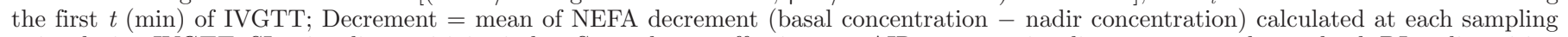
point during IVGTT; SI = insulin sensitivity index; $\mathrm{Sg}=$ glucose effectiveness; AIRg = acute insulin response to glucose load; DI = disposition

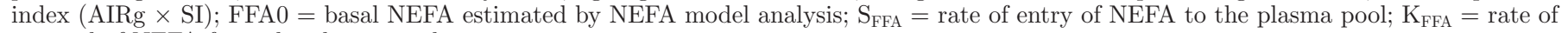
removal of NEFA from the plasma pool.

${ }^{2}$ Data of IVGTT $-10 \mathrm{~d}$ and $+10 \mathrm{~d}$ were combined and analyzed with ANOVA, a repeated measures model that included fixed effects of treatment and day, an interaction of treatment and day, and random effects of block and cow within block.

* P-values after logarithmic transformation. 

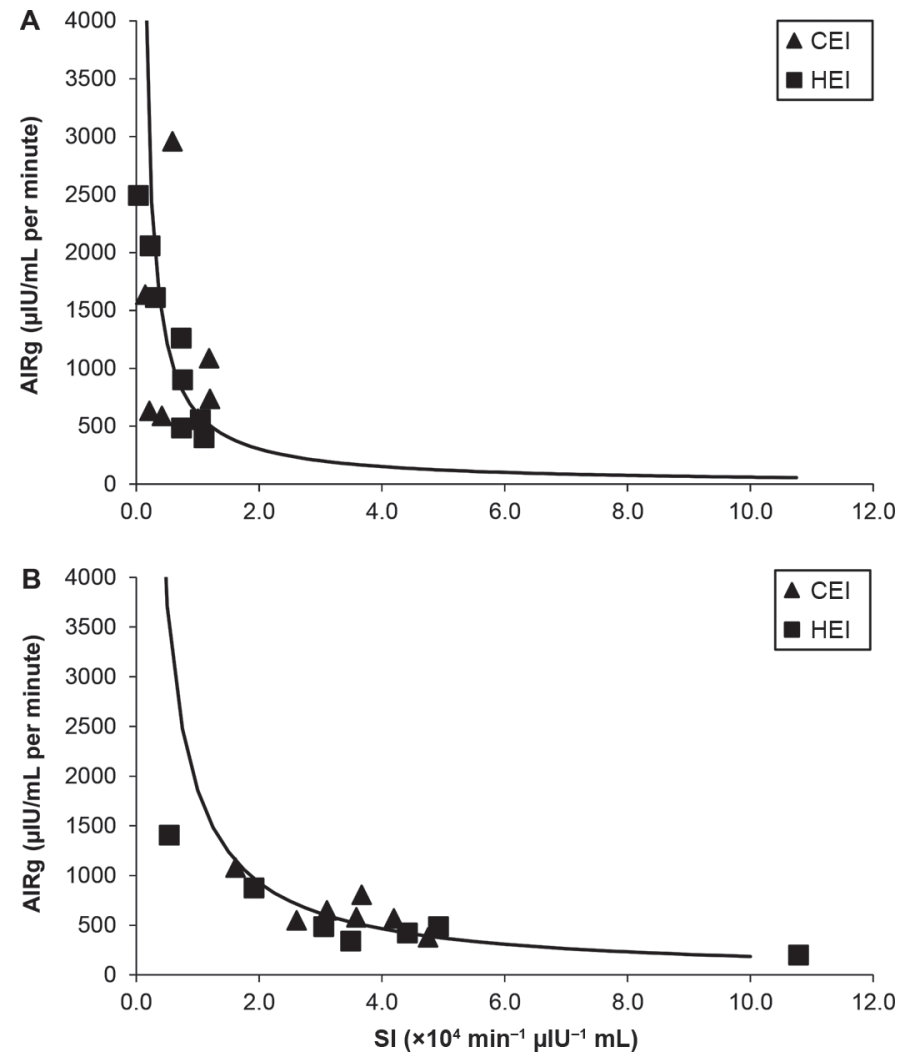

Figure 3. The hyperbolic relationship between the minimal modelderived indices of acute insulin secretion (AIRg) and insulin sensitivity index (SI) denoted as disposition index (DI) during the intravenous glucose tolerance tests $(0.25 \mathrm{~g}$ of glucose i.v. $/ \mathrm{kg}$ of BW) performed (A) $10 \pm 5 \mathrm{~d}$ before calving and (B) $10 \pm 1 \mathrm{~d}$ after parturition in dairy cows fed $100 \%$ of ME requirements throughout the 6 -wk dry period (CEI) and cows fed $144 \%$ of ME requirements during the early dry period followed by a gradual restriction of energy intake (119\% of ME requirements) during the last $3 \mathrm{wk}$ of gestation (HEI). The hyperbola was generated from extrapolated values of insulin secretion (AIRg) based on the average of observed values of DI for $-10 \mathrm{~d}$ and $+10 \mathrm{~d}$ and varying SI in the range from 0.0625 to 10 (Stefanovski et al., 2011). All observations of SI and AIRg in CEI and HEI before and after parturition are represented by the symbols defined in the figure.

nadir $(-0.51 ; P=0.06)$. The overall NEFA response to exogenous insulin was altered after parturition across the treatments as the $\mathrm{CR}_{30}$ of NEFA was lower (2.9 vs. $1.8 \% / \mathrm{min})$ and the basal NEFA (0.32 vs. $0.55 \mathrm{mmol} / \mathrm{L})$ and nadir NEFA (0.17 vs. $0.32 \mathrm{mmol} / \mathrm{L}$ ) were increased $(P<0.01$; Table 3$)$.

\section{DISCUSSION}

Our main purpose was to investigate whether overfeeding grass silage during the far-off dry period, combined with a close-up dry diet of commercial concentrates and decreasing energy allowance of grass silage, modifies the naturally occurring peripheral IR in dairy

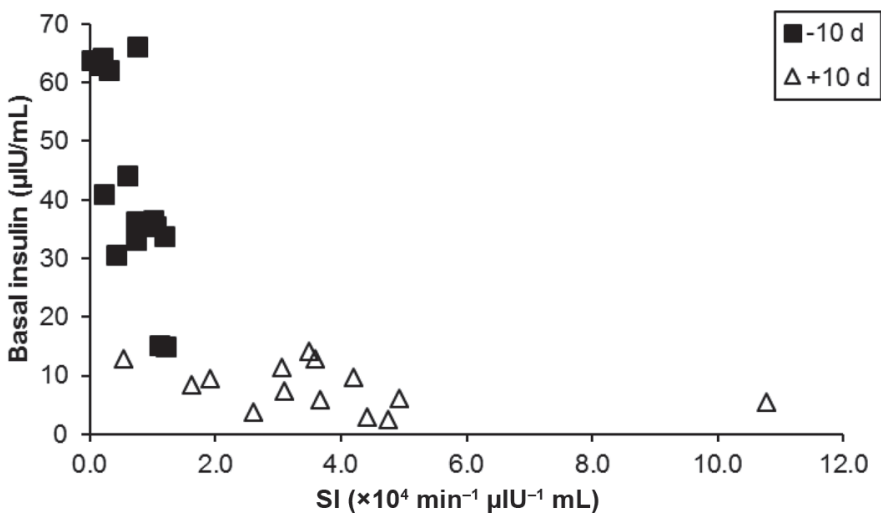

Figure 4. The hyperbolic relationship between basal plasma insulin concentration and the minimal model-derived index of insulin sensitivity (SI) during the intravenous glucose tolerance tests $(0.25 \mathrm{~g}$ of glucose $/ \mathrm{kg}$ of BW) performed $10 \pm 5 \mathrm{~d}$ before and $10 \pm 1 \mathrm{~d}$ after parturition in dairy cows fed $100 \%$ of ME requirements throughout the 6-wk dry period and cows fed $144 \%$ of ME requirements during the early dry period followed by a gradual restriction of energy intake (119\% of ME requirements) during the last 3 wk of gestation.

cows in the transition period compared with cows fed according to their energy requirements throughout the dry period. We anticipated that observed effects, if any, would carry over into early lactation. Additionally, we assessed time and diet $\times$ time interactions of metabolic responses related to glucose and insulin dynamics in periparturient dairy cows.

\section{Treatment Effects on Glucose and Insulin Dynamics}

Prepartal basal glucose and insulin levels were higher than postpartal concentrations regardless of the dietary treatment. Although no statistically significant difference between the treatments was observed before the IVGTT, the basal insulin concentration of overfed cows during the dry period tended to be greater than that of CEI cows, consistent with other studies (Holtenius et al., 2003; Janovick et al., 2011; Ji et al., 2012). The observed hyperinsulinemia is partly a result of a more positive energy balance (Holtenius et al., 2003). Hyperinsulinemia is also a compensatory mechanism for the deterioration of insulin sensitivity, a phenomenon that precedes impaired glucose tolerance and IR and is inadequate in Type 2 diabetes in humans (Ahrén and Pacini, 2004; Bergman, 2007). However, the finding that glucose and insulin responses to challenges were similar between treatments both post- and prepartum suggests that high EI combined with decreasing EI toward calving did not have adverse effects on glucose tolerance and insulin sensitivity and responsiveness of the cows during the transition period; this is in line with a recent report by Mann et al. (2016). An absence of 
dietary effects on glucose and insulin dynamics was also reported in late pregnant dry cows (Schoenberg and Overton, 2011). A more dramatic overfeeding during the dry period ( $178 \%$ of energy requirements), on the other hand, resulted in higher prepartal insulin levels and increased CR of glucose 3 wk prepartum. Postpartal glucose CR did not increase in a similar manner in overconditioned cows, suggesting that the animals were more insulin resistant $3 \mathrm{wk}$ after parturition, as assessed by glucose disposal during the IVGTT (Holtenius et al., 2003). The primary reason for the lack of effects of energy overfeeding on glucose CR seems to be that increased energy supply in terms of grass silage feeding did not affect BW or BCS changes during the close-up dry period or the lipid mobilization after calving. As shown by Holtenius et al. (2003) and De Koster et al. (2015), impaired insulin action is closely linked to overconditioning in transition dairy cows.

Earlier studies have shown that experimentally induced higher basal NEFA concentration may decrease glucose clearance during IVGTT, IC, or both (Pires et al., 2007; Salin et al., 2012; Schoenberg et al., 2012) because of reduced insulin sensitivity or responsiveness of peripheral tissues or as a result of altered insulin secretion and clearance (Salin et al., 2012; Schoenberg et al., 2012). Although the difference in prepartal basal NEFA concentrations between CEI and HEI cows had a magnitude similar to the difference between control and lipid-infused cows in an earlier study (Salin et al., 2012), we observed no difference in glucose clearance in the present study. The observed positive correlation between the basal NEFA concentration and the glucose
AUC during the postpartal IVGTT may suggest that increased plasma NEFA concentration plays a role in diminishing insulin-dependent glucose uptake. As postulated by Randle et al. (1963), an abundant availability of fatty acids and their oxidation inhibits the use of glucose as a substrate for cellular metabolism. The earlier works were conducted either before the close-up dry period (Salin et al., 2012) or with nonpregnant or fasted cows (Pires et al., 2007, 2008; Schoenberg et al., 2012), whereas in the present study glucose tolerance was assessed in pregnant animals during the transition period. Therefore, other factors contributing to the development of IR during the periparturient period (e.g., alterations in growth hormone, estrogen, and catecholamine concentrations) may have masked the effect of NEFA concentration on glucose disposal. Further, the number of animals used in our study was potentially too low to detect any minor effects of plasma NEFA on glucose clearance.

\section{Use of IVGTT and IC in the Investigation of the Periparturient Metabolic Adaptations}

Plasma glucose concentrations during the first $30 \mathrm{~min}$ of the IVGTT presumably exceeded the renal threshold for glucose excretion, which is approximately 200 $\mathrm{mg} / \mathrm{dL}(11 \mathrm{mmol} / \mathrm{L})$ in cattle (Bernhard et al., 2012). Consequently, the overall glucose clearance might have been overestimated to some extent (van Meirhaeghe et al., 1988). However, the proportion of glucose excreted in urine was probably relatively small. Grünberg et al. (2011) observed that 4 to $7 \%$ of dextrose was excreted

Table 3. Effects of dietary energy and decline in DMI during the dry period on plasma glucose and nonesterified fatty acid (NEFA) responses to intravenous insulin challenge (IC; $0.1 \mathrm{IU}$ of insulin i.v. $/ \mathrm{kg}$ of BW) performed $10 \pm 5 \mathrm{~d}$ (mean $\pm \mathrm{SD}$ ) before and $10 \pm 1 \mathrm{~d}$ after parturition in cows with a controlled energy intake (CEI) and those with a high energy intake (HEI)

\begin{tabular}{|c|c|c|c|c|c|c|c|c|}
\hline Item $^{1}$ & \multicolumn{2}{|c|}{$-10 \mathrm{~d}$} & \multicolumn{2}{|c|}{$+10 \mathrm{~d}$} & SEM & \multicolumn{3}{|c|}{$P$-value } \\
\hline Observations (no.) & 7 & 8 & 7 & 6 & & & & \\
\hline Basal (mmol/L) & 4.6 & 4.6 & 3.4 & 3.3 & 0.14 & 0.85 & $<0.01$ & 0.78 \\
\hline Nadir (mmol/L) & 2.6 & 2.5 & 1.6 & 1.4 & 0.13 & 0.28 & $<0.01$ & 0.81 \\
\hline $\mathrm{CR}_{30}(\% / \mathrm{min})$ & 1.4 & 1.7 & 2.6 & 2.5 & 0.14 & 0.65 & $<0.01$ & 0.34 \\
\hline Basal (mmol/L) & 0.37 & 0.28 & 0.50 & 0.60 & 0.06 & 0.94 & $<0.01$ & 0.13 \\
\hline Nadir $(\mathrm{mmol} / \mathrm{L})$ & 0.19 & 0.14 & 0.35 & 0.29 & 0.03 & 0.20 & $<0.01$ & 0.86 \\
\hline $\mathrm{CR}_{30}(\% / \mathrm{min})$ & 2.6 & 3.2 & 1.4 & 2.2 & 0.25 & 0.07 & $<0.01$ & 0.73 \\
\hline $\mathrm{AUC}_{30}$ & -1.2 & -1.3 & -1.7 & -2.0 & 0.53 & 0.78 & 0.40 & 0.89 \\
\hline $\mathrm{AUC}_{120}$ & 0.6 & 5.2 & 5.3 & 6.4 & 3.60 & 0.57 & 0.55 & 0.72 \\
\hline
\end{tabular}

${ }^{1}$ Basal $=$ average concentration at 15 and 5 min before IC; $\mathrm{CR}_{30}=$ clearance rate during the first 30 min of IC; AUC ${ }_{30}=$ area under the curve during the first $30 \mathrm{~min}$ of $\mathrm{IC} ; \mathrm{AUC}_{120}=$ area under the curve during $120 \mathrm{~min}$ of $\mathrm{IC}(\mathrm{mmol} / \mathrm{L} \times 30$ or $120 \mathrm{~min})$.

${ }^{2}$ Data of intravenous glucose tolerance test $-10 \mathrm{~d}$ and $+10 \mathrm{~d}$ were combined and analyzed with ANOVA, a repeated measures model that included fixed effects of treatment and day, an interaction of treatment and day, and random effects of block and cow within block. 
in the urine during the IVGTT conducted 3 to $5 \mathrm{~d}$ before parturition using a higher infusion dose than in our study (0.3-0.4 g/ $/ \mathrm{kg}$ of BW).

In accordance with earlier work (Holtenius et al., 2003; Bossaert et al., 2008; Mann et al., 2016), the glucose CR was greater after parturition than before parturition. This difference was at least partly attributable to the higher glucose uptake by the mammary gland in comparison with the gravid uterus (De Koster and Opsomer, 2013), although changes in the glucose uptake by insulin-sensitive tissues may also have contributed to the glucose clearance. Interestingly, studies by Grünberg et al. (2011) and Zachut et al. (2013) observed no difference in the $\mathrm{CR}$ of glucose between the pre- and postpartal IVGTT. In both of these studies, the insulin response to a similar or greater glucose load was considerably smaller after parturition than in the present study. The differences in duration of feed withdrawal may account for varying $\mathrm{CR}$ results because insulin secretion is attenuated and glucose clearance is reduced during fasting (Schoenberg et al., 2012). In the study by Zachut et al. (2013), no feed was allowed for $12 \mathrm{~h}$ before the IVGTT, whereas in our study and the studies by Holtenius et al. (2003) and Bossaert et al. (2008) the fasting period was 1 to $3.5 \mathrm{~h}$. Differences between the studies in glucose $\mathrm{CR}$ and insulin response to a glucose challenge suggest that glucose uptake to the insulin-responsive tissues may represent a considerable proportion of glucose utilization during the early stage of IVGTT in early-lactation cows in a fed state, as also indicated by the calculated glucose use. Zachut et al. (2013) suggested that hyperphysiological amounts of glucose during the IVGTT may be beyond the glucose uptake rate of the mammary gland. Based on the calculated glucose use, tissues other than mammary gland used $45 \%$ of the infused glucose in the first 30 min of the postpartal IVGTT. In accordance with the prioritization for milk production, the glucose use of other tissues was decreased after calving relative to late pregnancy. However, when the calculated glucose use of other tissues during the first $30 \mathrm{~min}$ of IVGTT is divided by insulin $\mathrm{AUC}_{30}$, the glucose use per $\mathrm{AUC}$ unit of insulin was higher after calving than during late pregnancy (20 vs. $12 \mathrm{mg} / \mu \mathrm{IU}$ per milliliter $\times 30 \mathrm{~min}$ ). This suggests that whole-body insulin sensitivity is increased during early lactation compared with late pregnancy. The apparent conflict of increased insulin sensitivity with the need to spare glucose for milk synthesis can be explained by the primary role of insulin concentration in the regulation of glucose usage. This is illustrated by the ratio of glucose use of other tissues during the first 60 min of IVGTT relative to insulin $\mathrm{AUC}_{60}$ pre- and postpartum $(9.6 \mathrm{mg} / \mu \mathrm{IU}$ per milliliter $\times 60 \mathrm{~min}$ vs. $9.5 \mathrm{mg} / \mu \mathrm{IU}$ per milliliter $\times 60 \mathrm{~min})$. This indicates that the difference in tissue responsiveness to insulin between pre- and postpartum IVGTT is observed only at high insulin levels during the very early stage of IVGTT. Therefore, the low insulin concentration postpartum is most likely the main factor regulating glucose utilization by peripheral tissues during early lactation. As shown in this study, the decreased insulin concentration results from a lower response to a similar secretory stimulus (Bossaert et al., 2008; Kerestes et al., 2009) and increased clearance.

\section{Assessment of Insulin Sensitivity Using the MM}

The MM estimates have not been widely used in ruminants. Although the major energy substrate (the ruminally derived VFA of the cows in a fed state) differs from that of humans, previous investigations have shown that glucose MM parameters of lactating dairy cows are similar in magnitude to those reported for humans (Boston et al., 2006). This implies that, in ruminants, the MM parameters are equally related to the central processes of glucose metabolism and its control by insulin (Moate et al., 2007). However, given that the insulin-independent glucose uptake by the mammary gland may constitute 80 to $90 \%$ of the glucose disposal during early lactation (Bauman and Currie, 1980; De Koster and Opsomer, 2013), the results of MM analyses of the early-lactation dairy cow should be interpreted with caution, and further research is warranted in this area.

The estimated prepartal SI values were within the range of values reported in the dry pregnant cows (Salin et al., 2012; De Koster et al., 2016). The postpartal values were similar to or lower than those of lactating cows (Stanley, 2005; Moate et al., 2007; Marett et al., 2015) and lower than those reported in calves (Bunting et al., 2000). The MM index SI suggests improved whole-body insulin sensitivity postpartum when compared with prepartum values. Prepartal SI was very low, and AIRg was higher to compensate for the reduced insulin sensitivity. The postpartal AIRg was less pronounced because of a higher SI value resulting in a greater DI, reflecting improved overall glucose tolerance. As Figure 3 illustrates, the prepartal values of SI have a left and upward shift, which indicates a state of impaired insulin sensitivity (Kahn, 1978). In accordance with our results, Stanley (2005) reported that SI increased from prepartum to postpartum in dairy cows fed either 105 or $145 \%$ of the energy requirements of the dry cow. The SI values were 3 -fold higher postpartum and the DI increased by a similar degree, which together imply an improved insulin sensitivity and glucose tolerance (Bergman et al., 1981). The DI, defined as the product of AIRg and SI, characterizes 
the hyperbolic relationship between insulin sensitivity and the secretion of insulin. The DI characterizes the ability of $\beta$ cells to compensate for the variations in SI by altering the insulin response to preserve glucose tolerance (Bergman et al., 1981; Kahn et al., 1993; Bergman, 2007). Therefore, the $\beta$ cells of the pancreas were less sensitive to compensate for the decreased insulin sensitivity prepartum because, regardless of the higher basal and challenged insulin levels, the DI was smaller before calving than after calving. These results may insinuate that the reduced basal insulin concentration in early-lactating dairy cows allows a moderate increase in insulin sensitivity of the insulin-dependent tissues (skeletal muscle and adipose tissue).

The observed hyperbolic relationship between the basal insulin and the SI across all cows (Figure 4) is in agreement with Kahn et al. (1993) and suggests that relatively small changes in SI may generate substantial alterations in the basal insulin. The former implies that when SI is low (e.g., under 2.0; Figure 4) and the IR is manifest, small fluctuations in insulin sensitivity would be associated with relatively large adjustments in the fasting insulin (Bergman et al., 1981). Indeed, Kräft (2004) reported comparable results in transition dairy cows, demonstrating that the SI of dry cows deteriorated in comparison with clinically healthy earlylactating cows (4-10 wk postpartum). Our results agree with those of Kräft (2004), suggesting that a decreased insulin concentration in early lactation facilitates the flow of glucose to the udder while the enhanced insulin sensitivity and response of peripheral tissues prevent a critical deficiency of nutrient flow to extra mammary tissues. Recently, Marett et al. (2015) found that differences during IVGTT in dynamics of plasma metabolites and insulin in cows on an extended lactation resulted primarily from the production stage. Diet did not have an effect on the responses, and the actions of insulin occurred independently of feed intake (Schoenberg et al., 2012; Marett et al., 2015). Similarly, Mashek et al. (2001) reported that cows in mid lactation (wk 17) needed a lower amount (24\%) of glucose to maintain euglycemia during a hyperinsulinemic-euglycemic test than did cows in early lactation (wk 4). The glucose infusion rate was reduced despite a $36 \%$ higher insulin concentration during the mid-lactation clamp. The authors suggested that this may indicate lower insulin sensitivity of peripheral tissues in mid lactation than in early lactation. A recent study demonstrated that insulin response to glucose load was greater at 150 DIM than at 50 or 100 DIM, as insulin AUC was greater at 150 DIM but glucose CR and AUC were unaltered (Oliveira et al., 2016). Taken together, the interplay between the insulin sensitivity of the peripheral tissues and insulin secretion facilitates adaptation for the early-lactation dairy cow to variations in dietary composition and EI.

\section{NEFA Responses During IVGTT and IC}

During the first $10 \mathrm{~min}$ of pre- and postpartal IVGTT, a latency period was observed during which plasma NEFA remained refractory to insulin as a result of a delay in both insulin transport and signaling (Sumner et al., 2004). A latency period was also reported in previous studies with cows (Moate et al., 2007; Salin et al., 2012). The decline in plasma NEFA concentration after the latency period represents a block of lipolysis by an inhibition of hormone-sensitive lipase. The CR of NEFA in the IVGTT was not affected by physiological state or dietary treatment, suggesting that the sensitivity of the adipose tissue to insulin remained unchanged. However, a decreased CR of NEFA and higher nadir of NEFA during the postpartal IC suggests a diminished maximal inhibition of lipolysis by insulin, consistent with increased sensitivity to lipolytic stimulation by factors such as growth hormone and catecholamines in early lactation (McNamara, 1997; Bauman, 2000). The decrease in responsiveness to insulin seems to have commenced before calving because the cows with a shorter interval to actual calving day at the time of the prepartal IC tended to have a lower NEFA CR. The observed tendency for a difference in CR of NEFA between CEI and HEI cows in IC may not indicate altered responsiveness of adipose tissue to antilipolytic actions of insulin given that NEFA was reduced to a similar nadir (Patton et al., 2009). The strong rebound of plasma NEFA concentration 60 min after glucose infusion in postpartal IVGTT indicates resumption of lipolysis, potentially because of the increasing plasma adrenaline concentration (Sumner et al., 2004) and increased sensitivity of adipose tissue to lipolytic stimulation (Drackley et al., 2005; Kokkonen et al., 2005; Roche et al., 2013). Indeed, Theilgaard et al. (2002) showed that the lipolytic response to adrenaline challenge was greatly increased in the early lactation period.

\section{Treatment Effects on NEFA Suppression}

The blunted NEFA response of HEI cows in prepartal IVGTT suggests that the adipose tissue response to an exogenous glucose load was affected by the EI during the prepartum period. However, the effect did not carry over to the early lactation period, which was inconsistent with our hypothesis. In agreement with our results in prepartal cows, Schoenberg et al. (2012) observed that dry cows fed a high-energy diet had lower NEFA suppression in the fed state than cows fed a low-energy diet. Patton et al. (2009) studied strain differences in 
homeostatic challenges in early lactation and found that North American strains of Holstein-Friesian cattle with higher basal NEFA had a greater suppression of NEFA after IC in early lactation (32 d postpartum) compared with New Zealand-type Holstein-Friesian cattle despite an identical loss of BCS and a similar glucose response. According to the authors, the NEFA decrement was attributable to the higher basal NEFA, as both strains decreased to a similar nadir of NEFA. Similarly, Schoenberg et al. (2012) stated that the higher basal NEFA concentration might have influenced the greater NEFA decrement in the IVGTT in cows fed at a lower plane of nutrition. Correspondingly, the negative correlation between the basal NEFA and the NEFA AUC suggests that the basal NEFA concentration affects the magnitude of the depression of NEFA after the glucose load. Finally, individual differences in the regulation of lipolysis may have contributed to the transitory effect of the dry period EI on the plasma NEFA responses (Patton et al., 2009; Weber et al., 2013). For instance, accretion of lipids between different adipose tissue sites varies in dairy cows (Drackley et al., 2014), and altered responses and sensitivity to catecholamines may mediate adipose tissue mobilization (Chilliard et al., 2000; Drackley et al., 2005; Roche et al., 2013). Additionally, Theilgaard et al. (2002) observed that lipolytic response to adrenaline challenge was increased with increasing body fatness in the dry period and in mid lactation but not in early lactation. Taken together, the results imply that, although insulin is partly responsible for the basal variation of NEFA and effectively inhibits lipolysis during the IVGTT, other mechanisms (e.g., the extent of and sensitivity to the catecholamine stimulation) are also involved in the modification of adipose tissue responses to glucose stimulus.

\section{CONCLUSIONS}

Overfeeding grass silage during the far-off dry period combined with decreasing EI and concentrate feeding during the close-up dry period did not have adverse effects on the metabolic flexibility of the transition dairy cow as assessed by the IVGTT and the IC at $10 \mathrm{~d}$ before the expected calving and d 10 postpartum. Peripheral tissue glucose tolerance and insulin response to glucose in the periparturient dairy cows followed a similar pattern regardless of the prepartal nutritional status. The oversupply of energy during the dry period resulted in blunted insulin-mediated NEFA suppression of the adipose tissue before parturition compared with controlled EI. The strong association between basal and challenged NEFA implies that the response of NEFA was largely driven by basal NEFA concentration. The observed effects in the level of adipose tissue regulation by insulin were transitional and, contrary to our hypotheses, did not carry over from late pregnancy into early lactation. The MM-derived estimates and the differences in glucose and insulin dynamics during the IVGTT pre- and postpartum suggest that overall glucose tolerance and sensitivity to insulin were enhanced after parturition across the treatments. Further research is required to verify the feasibility of the MM analysis in assessing the insulin and glucose dynamics of the periparturient dairy cow. The current results imply that the decrease in insulin concentration near calving is a major factor directing glucose to the mammary gland and that the role of peripheral insulin sensitivity is of less importance.

\section{ACKNOWLEDGMENTS}

The authors gratefully acknowledge the assistance of Pirjo Pursiainen, Juha Suomi, and the staff at the research farm of the University of Helsinki (Finland) for their care of experimental animals and the assistance of the laboratory staff of the Department of Agricultural Sciences, University of Helsinki. We also extend our gratitude to Rashid Safari (University of Tabriz, Tabriz, Iran) for assistance in handling the data. This study was funded by the Ministry of Agriculture and Forestry, Finland. Raisio plc Research Foundation (Raisio, Finland) supported the first author financially.

\section{REFERENCES}

Agenäs, S., E. Burstedt, and K. Holtenius. 2003. Effects of feeding intensity during the dry period. 1 . Feed intake, body weight, and milk production. J. Dairy Sci. 86:870-882.

Ahrén, B., and G. Pacini. 2004. Importance of quantifying insulin secretion in relation to insulin sensitivity to accurately assess beta cell function in clinical studies. Eur. J. Endocrinol. 150:97-104.

Bauman, D. E. 2000. Regulation of nutrient partitioning during lactation: Homeostasis and homeorhesis revisited. Pages 311-327 in Ruminant Physiology: Digestion, Metabolism and Growth and Reproduction. P. B. Cronje, ed. CABI Publishing, New York, NY.

Bauman, D. E., and W. B. Currie. 1980. Partitioning of nutrients during pregnancy and lactation: A review of mechanisms involving homeostasis and homeorhesis. J. Dairy Sci. 63:1514-1529.

Bell, A. W., and D. E. Bauman. 1997. Adaptations of glucose metabolism during pregnancy and lactation. J. Mammary Gland Biol. Neoplasia 2:265-278.

Bergman, R. N. 1989. Toward physiological understanding of glucose tolerance. Minimal-model approach. Diabetes 38:1512-1527.

Bergman, R. N. 2007. Orchestration of glucose homeostasis: From a small acorn to the California oak. Diabetes 56:1489-1501.

Bergman, R. N., L. S. Phillips, and C. Cobelli. 1981. Physiologic evaluation of factors controlling glucose tolerance in man: Measurement of insulin sensitivity and beta-cell glucose sensitivity from the response to intravenous glucose. J. Clin. Invest. 68:1456-1467.

Bernhard, B. C., N. C. Burdick, R. J. Rathmann, J. A. Carroll, D. N. Finck, M. A. Jennings, T. R. Young, and B. J. Johnson. 2012 Chromium supplementation alters both glucose and lipid metabo- 
lism in feedlot cattle during the receiving period. J. Anim. Sci. 90:4857-4865.

Bossaert, P., J. L. M. R. Leroy, S. De Vliegher, and G. Opsomer. 2008. Interrelations between glucose-induced insulin response, metabolic indicators, and time of first ovulation in high-yielding dairy cows. J. Dairy Sci. 91:3363-3371.

Boston, R., D. Stefanovski, P. Moate, O. Linares, and P. Greif. 2003. Cornerstones to shape modeling for the 21st century: Introducing the AKA-glucose project. Adv. Exp. Med. Biol. 537:21-42.

Boston, R. C., and P. J. Moate. 2008. A novel minimal model to describe NEFA kinetics following an intravenous glucose challenge. Am. J. Physiol. Regul. Integr. Comp. Physiol. 294:R1140-R1147.

Boston, R. C., P. J. Moate, and D. Stefanovski. 2006. Modeling the glucose challenge in dairy cows. Can. J. Anim. Sci. 86:569. (Abstr.)

Bunting, L. D., T. A. Tarifa, B. T. Crochet, J. M. Fernandez, C. L. Depew, and J. C. Lovejoy. 2000. Effects of dietary inclusion of chromium propionate and calcium propionate on glucose disposal and gastrointestinal development in dairy calves. J. Dairy Sci. 83:2491-2498.

Chilliard, Y., A. Ferlay, Y. Faulconnier, M. Bonnet, J. Rouel, and F. Bocquier. 2000. Adipose tissue metabolism and its role in adaptations to undernutrition in ruminants. Proc. Nutr. Soc. 59:127-134.

Dann, H. M., N. B. Litherland, J. P. Underwood, M. Bionaz, A D'Angelo, J. W. McFadden, and J. K. Drackley. 2006. Diets during far-off and close-up dry periods affect periparturient metabolism and lactation in multiparous cows. J. Dairy Sci. 89:3563-3577.

De Koster, J., M. Hostens, K. Hermans, W. Van den Broeck, and G. Opsomer. 2016. Validation of different measures of insulin sensitivity of glucose metabolism in dairy cows using the hyperinsulinemic euglycemic clamp test as the gold standard. Domest. Anim. Endocrinol. 57:117-126. https://doi.org/10.1016/j. domaniend.2016.06.004.

De Koster, J., M. Hostens, M. Van Eetvelde, K. Hermans, S. Moerman, H. Bogaert, E. Depreester, B. Van, and G. Opsomer. 2015. Insulin response of the glucose and fatty acid metabolism in dry dairy cows across a range of body condition scores. J. Dairy Sci. 98:4580-4592.

De Koster, J. D., and G. Opsomer. 2013. Insulin resistance in dairy cows. Vet. Clin. North Am. Food Anim. Pract. 29:299-322.

Dewhurst, R. J., D. W. R. Davies, and W. J. Fisher. 2009. Effects of silage digestibility on intake and body reserves of dry cows and performance in the first part of the next lactation. Animal 3:1721-1727.

Douglas, G. N., T. R. Overton, H. G. Bateman II, H. M. Dann, and J. K. Drackley. 2006. Prepartal plane of nutrition, regardless of dietary energy source, affects periparturient metabolism and dry matter intake in Holstein cows. J. Dairy Sci. 89:2141-2157.

Drackley, J. K., H. M. Dann, G. N. Douglas, N. A. Janovick Guretzky, N. B. Litherland, J. P. Underwood, and J. J. Loor. 2005. Physiological and pathological adaptations in dairy cows that may increase susceptibility to periparturient diseases and disorders. Ital. J. Anim. Sci. 4:323-344.

Drackley, J. K., R. L. Wallace, D. Graugnard, J. Vasquez, B. F. Richards, and J. J. Loor. 2014. Visceral adipose tissue mass in nonlactating dairy cows fed diets differing in energy density. J. Dairy Sci. 97:3420-3430.

Edmonson, A. J., I. J. Lean, L. D. Weaver, T. Farver, and G. Webster. 1989. A body condition scoring chart for Holstein dairy cows. J. Dairy Sci. 72:68-78.

Grummer, R. R., D. G. Mashek, and A. Hayirli. 2004. Dry matter intake and energy balance in the transition period. Vet. Clin. North Am. Food Anim. Pract. 20:447-470.

Grünberg, W., S. S. Donkin, and P. D. Constable. 2011. Periparturient effects of feeding a low dietary cation-anion difference diet on acidbase, calcium, and phosphorus homeostasis and on intravenous glucose tolerance test in high-producing dairy cows. J. Dairy Sci. 94:727-745

Holtenius, K., S. Agenas, C. Delavaud, and Y. Chilliard. 2003. Effects of feeding intensity during the dry period. 2. Metabolic and hormonal responses. J. Dairy Sci. 86:883-891.
Janovick, N. A., Y. R. Boisclair, and J. K. Drackley. 2011. Prepartum dietary energy intake affects metabolism and health during the periparturient period in primiparous and multiparous Holstein cows. J. Dairy Sci. 94:1385-1400.

Janovick, N. A., and J. K. Drackley. 2010. Prepartum dietary management of energy intake affects postpartum intake and lactation performance by primiparous and multiparous Holstein cows. J. Dairy Sci. 93:3086-3102.

Ji, P., J. S. Osorio, J. K. Drackley, and J. J. Loor. 2012. Overfeeding a moderate energy diet prepartum does not impair bovine subcutaneous adipose tissue insulin signal transduction and induces marked changes in peripartal gene network expression. J. Dairy Sci. 95:4333-4351.

Kahn, C. R. 1978. Insulin resistance, insulin insensitivity, and insulin unresponsiveness: A necessary distinction. Metabolism 27:18931902.

Kahn, S. E., R. L. Prigeon, D. K. McCulloch, E. J. Boyko, R. N. Bergman, M. W. Schwartz, J. L. Neifing, W. K. Ward, J. C. Beard, and J. P. Palmer. 1993. Quantification of the relationship between insulin sensitivity and $\beta$-cell function in human subjects: Evidence for a hyperbolic function. Diabetes 42:1663-1672.

Kerestes, M., V. Faigl, M. Kulcsar, O. Balogh, J. Foldi, H. Febel, Y. Chilliard, and G. Huszenicza. 2009. Periparturient insulin secretion and whole-body insulin responsiveness in dairy cows showing various forms of ketone pattern with or without puerperal metritis. Domest. Anim. Endocrinol. 37:250-261.

Kokkonen, T., J. Taponen, T. Anttila, L. Syrjälä-Qvist, C. Delavaud, Y. Chilliard, M. Tuori, and A. T. Tesfa. 2005. Effect of body fatness and glucogenic supplement on lipid and protein mobilization and plasma leptin in dairy cows. J. Dairy Sci. 88:1127-1141.

Kräft, S. 2004. Charakterisierung der peripheren insulin-response und insulin-sensitivität bei trockenstehenden, laktierenden und leberverfetteten milchkühen ohne und mit ketose mittels hyperinsulinämischer, euglycämischer clamps. PhD Thesis. Tierärztliche Hochschule, Hannover, Germany.

Natural Resources Institute Finland. 2015. Feed tables and nutrient requirements. Accessed Oct. 5, 2015. https://portal.mtt.fi/portal/ page/portal/Rehutaulukot/feed_tables_english/feed_tables.

Mann, S., F. A. L. Yepes, M. Duplessis, J. J. Wakshlag, T. R. Overton, B. P. Cummings, and D. V. Nydam. 2016. Dry period plane of energy: Effects on glucose tolerance in transition dairy cows. J. Dairy Sci. 99:701-717.

Marett, L. C., M. J. Auldist, P. J. Moate, W. J. Wales, K. L. Macmillan, F. R. Dunshea, and B. J. Leury. 2015. Response of plasma glucose, insulin, and nonesterified fatty acids to intravenous glucose tolerance tests in dairy cows during a 670-day lactation. J. Dairy Sci. 98:179-189

Mashek, D. G., K. L. Ingvartsen, J. B. Andersen, M. Vestergaard, and T. Larsen. 2001. Effects of a four-day hyperinsulinemic-euglycemic clamp in early and mid-lactation dairy cows on plasma concentrations of metabolites, hormones, and binding proteins. Domest. Anim. Endocrinol. 21:169-185.

McNamara, J. P. 1997. Adipose tissue metabolism during lactation: Where do we go from here? Proc. Nutr. Soc. 56:149-167.

Moate, P. J., J. R. Roche, L. M. Chagas, and R. C. Boston. 2007. Evaluation of a compartmental model to describe non-esterified fatty acid kinetics in Holstein dairy cows. J. Dairy Res. 74:430-437.

Oliveira, L. H., A. B. Nascimento, P. L. J. Monteiro Jr., M. M. Guardieiro, M. C. Wiltbank, and R. Sartori. 2016. Development of insulin resistance in dairy cows by 150 days of lactation does not alter oocyte quality in smaller follicles. J. Dairy Sci. 99:9174-9183.

Patton, J., J. J. Murphy, F. P. O'Mara, and S. T. Butler. 2009. Responses of North American and New Zealand strains of HolsteinFriesian dairy cattle to homeostatic challenges during early and mid-lactation. Animal 3:251-260.

Petterson, J. A., F. R. Dunshea, R. A. Ehrhardt, and A. W. Bell. 1993. Pregnancy and undernutrition alter glucose metabolic responses to insulin in sheep. J. Nutr. 123:1286-1295.

Pires, J. A. A., J. B. Pescara, A. E. Brickner, N. S. Del Rio, A. P. Cunha, and R. R. Grummer. 2008. Effects of abomasal infusion of 
linseed oil on responses to glucose and insulin in Holstein cows. J. Dairy Sci. 91:1378-1390.

Pires, J. A. A., A. H. Souza, and R. R. Grummer. 2007. Induction of hyperlipidemia by intravenous infusion of tallow emulsion causes insulin resistance in Holstein cows. J. Dairy Sci. 90:2735-2744.

Randle, P. J., P. B. Garland, C. N. Hales, and E. A. Newsholme. 1963. The glucose fatty-acid cycle. Its role in insulin sensitivity and the metabolic disturbances of diabetes mellitus. Lancet 1:785-789.

Rao, D. R., H. M. Hegarty, and B. L. Larson. 1975. Effect of cell density on lactose synthesis in bovine mammary cell cultures. J. Dairy Sci. 58:159-163.

Remppis, S., H. Steingass, L. Gruber, and H. Schenkel. 2011. Effects of energy intake on performance, mobilization and retention of body tissue, and metabolic parameters in dairy cows with special regard to effects of pre-partum nutrition on lactation-A review. Asianaustralas. J. Anim. Sci. 24:540-572.

Roche, J. R., A. W. Bell, T. R. Overton, and J. J. Loor. 2013. Nutritional management of the transition cow in the 21st century-A paradigm shift in thinking. Anim. Prod. Sci. 53:1000-1023.

Roche, J. R., N. C. Friggens, J. K. Kay, M. W. Fisher, K. J. Stafford, and D. P. Berry. 2009. Invited review: Body condition score and its association with dairy cow productivity, health, and welfare. J. Dairy Sci. 92:5769-5801. https://doi.org/10.3168/jds.2009-2431.

Salin, S., J. Taponen, K. Elo, I. Simpura, A. Vanhatalo, R. Boston, and T. Kokkonen. 2012. Effects of abomasal infusion of tallow or camelina oil on responses to glucose and insulin in dairy cows during late pregnancy. J. Dairy Sci. 95:3812-3825.

Sano, H., S. Narahara, T. Kondo, A. Takahashi, and Y. Terashima. 1993. Insulin responsiveness to glucose and tissue responsiveness to insulin during lactation in dairy cows. Domest. Anim. Endocrinol. 10:191-197.

Schoenberg, K. M., R. M. Ehrhardt, and T. R. Overton. 2012. Effects of plane of nutrition and feed deprivation on insulin responses in dairy cattle during late gestation. J. Dairy Sci. 95:670-682.

Schoenberg, K. M., and T. R. Overton. 2011. Effects of plane of nutrition and 2,4-thiazolidinedione on insulin responses and adipose tissue gene expression in dairy cattle during late gestation. J. Dairy Sci. 94:6021-6035.

Selim, S., S. Salin, J. Taponen, A. Vanhatalo, T. Kokkonen, and K. T. Elo. 2014. Prepartal dietary energy alters transcriptional adaptations of the liver and subcutaneous adipose tissue of dairy cows during the transition period. Physiol. Genomics 46:328-337.
Shiang, K. 2004. The SAS calculations of areas under the curve (AUC) for multiple metabolic readings. Accessed Oct. 22, 2015. http://www.lexjansen.com/wuss/2004/posters/c_post_the_sas_ calculations_.pdf.

Smith, K. L., M. R. Waldron, T. R. Overton, J. K. Drackley, R. C. Boston, and M. T. Socha. 2004. Effects of physiological state, prepartum dietary carbohydrate source, and chromium supplementation on dynamics of insulin, glucose, and fatty acid metabolism in dairy cows. J. Dairy Sci. 87(Suppl. 1):442. (Abstr.)

Stanley, C. C. 2005. Regulation of glucose metabolism in dairy cattle. $\mathrm{PhD}$ Thesis. Louisiana State University, Baton Rouge.

Stefanovski, D., J. M. Richey, O. Woolcott, M. Lottati, D. Zheng, L. N. Harrison, V. Ionut, S. P. Kim, I. Hsu, and R. N. Bergman. 2011 Consistency of the disposition index in the face of diet induced insulin resistance: Potential role of FFA. PLoS ONE 6:e18134.

Sumner, A. E., R. N. Bergman, G. L. Vega, D. J. Genovese, C. S. Cochran, K. Pacak, R. M. Watanabe, and R. C. Boston. 2004 The multiphasic profile of free fatty acids during the intravenous glucose tolerance test is unresponsive to exogenous insulin. Metabolism 53:1202-1207.

Swislocki, A. L., Y. D. Chen, A. Golay, M. O. Chang, and G. M. Reaven. 1987. Insulin suppression of plasma-free fatty acid concentration in normal individuals and patients with type 2 (noninsulin-dependent) diabetes. Diabetologia 30:622-626.

Theilgaard, P., N. C. Friggens, K. H. Sloth, and K. L. Ingvartsen 2002. The effect of breed, parity and body fatness on the lipolytic response of dairy cows. Anim. Sci. 75:209-219.

Vernon, R. G., and C. M. Pond. 1997. Adaptations of maternal adipose tissue to lactation. J. Mammary Gland Biol. Neoplasia 2:231-241.

van Meirhaeghe, H., P. Deprez, C. D. Hende, and E. Muylle. 1988. Plasma glucose clearance and insulin response in cows with abomasal displacement. Zentralbl. Veterinarmed A 35:221-228.

Weber, C., C. Hametner, A. Tuchscherer, B. Losand, E. Kanitz, W. Otten, S. P. Singh, R. M. Bruckmaier, F. Becker, W. Kanitz, and H. M. Hammon. 2013. Variation in fat mobilization during early lactation differently affects feed intake, body condition, and lipid and glucose metabolism in high-yielding dairy cows. J. Dairy Sci. 96:165-180.

Zachut, M., H. Honig, S. Striem, Y. Zick, S. Boura-Halfon, and U. Moallem. 2013. Periparturient dairy cows do not exhibit hepatic insulin resistance, yet adipose-specific insulin resistance occurs in cows prone to high weight loss. J. Dairy Sci. 96:5656-5669. 